\title{
School climate and indicators of stress, anxiety, and depression in teachers of private technical high school
}

\author{
Osvaldo André Filippsen ${ }^{1}$ \\ (iD) https://orcid.org/0000-0002-7377-9567 \\ Angela Helena Marin ${ }^{2}$ \\ iD https://orcid.org/0000-0002-8056-8661
}

\begin{abstract}
How to cite this article: Filippsen, O. A., \& Marin, A. H. (2020). School climate and indicators of stress, anxiety, and depression in teachers of private technical high school. Psicologia: Teoria e Prática, 22(3), 247-262. doi:10.5935/1980-6906/psicologia. v22n3p247-262
\end{abstract}

Submission: 07/30/2019

Acceptance: 06/25/2020

1 Porto Alegre Technical Institute of Education (Fatepa), Porto Alegre, RS, Brazil.

2 Federal University of Rio Grande do Sul (UFRGS), Porto Alegre, RS, Brazil. 


\begin{abstract}
This study examined the contribution and the extent to which the school climate affects the indicators of stress, anxiety, and depression in teachers of private technical high school. An analytical observational design was used with the participation of 62 teachers who completed the Sociodemographic and Labor Questionnaire, the Depression, Anxiety and Stress Scale - 21, and the Delaware School Climate Survey-Teacher/Staff. Analyses indicated weak correlations between considered variables. Fairness of rules negative perception explained $16 \%$ of variance of depression and $15 \%$ of stress, while safety negative perception explained $14 \%$ of the variance of anxiety. Despite the low intensity of stress, anxiety, and depression indicators, the fairness of rules and safety are factors that can affect the mental health of teachers, which need to be considered, because they may impact the quality of teaching and learning.
\end{abstract}

Keywords: school climate; stress; anxiety; depression; teachers.

\title{
CLIMA ESCOLAR E INDICADORES DE ESTRESSE, ANSIEDADE E DEPRESSÃO EM PROFESSORES DO ENSINO TÉCNICO MÉDIO PRIVADO
}

\begin{abstract}
Resumo
Este estudo examinou a contribuição e a extensão em que o clima escolar afeta os indicadores de estresse, ansiedade e depressão em professores do ensino técnico médio privado. Utilizou-se um delineamento observacional analítico de corte transversal, com 62 professores que preencheram o Questionário Sociodemográfico e Laboral, a Depression, Anxiety and Stress Scale-21 e o Delaware School Climate Survey- Teacher/Staff. As análises indicaram correlações fracas entre as variáveis consideradas. A percepção negativa sobre a justiça das regras explicou $16 \%$ da variância da depressão e 15\% do estresse, enquanto a percepção negativa de segurança explicou $14 \%$ da variância da ansiedade. Apesar da baixa intensidade de indicadores de estresse, ansiedade e depressão identificada, destaca-se que a justiça das regras e a segurança são fatores que podem afetar a saúde mental docente, os quais precisam ser considerados porque há a possibilidade de eles impactarem a qualidade do ensino-aprendizagem.
\end{abstract}

Palavras-chave: clima escolar; estresse; ansiedade; depressão; professores. 


\title{
CLIMA ESCOLAR Y LOS INDICADORES DE ESTRÉS, ANSIEDAD Y DEPRESIÓN EN PROFESORES DE LA EDUCACIÓN TÉCNICA PRIVADA
}

\begin{abstract}
Resumen
Este estudio examinó la contribución y el grado en que el clima escolar influye en los indicadores de estrés, ansiedad y depresión en los profesores de la educación técnica privada. Se utilizó un diseño analítico observacional de corte transversal con 62 profesores que completaron el Cuestionario Sociodemográfico, la Depression, Anxiety and Stress Scale-21 y la Delaware School Climate Survey-Teacher/Staff. Los análisis indicaron correlaciones débiles entre las variables consideradas. La percepción negativa de la equidad de las reglas explica $16 \%$ de la variación de la depresión y 15\% del estrés, mientras que la percepción negativa de la seguridad explica 14\% de la variación de la ansiedad. A pesar de la baja intensidad de los indicadores de estrés, ansiedad y depresión, la imparcialidad de las reglas y la seguridad son factores que producen daño a la salud mental de los docentes, que deben tenerse en cuenta porque pueden afectar la calidad de la enseñanza y el aprendizaje.

Palabras clave: clima escolar; estrés; ansiedad; depresión; profesores.
\end{abstract}

\section{Introduction}

The primary function of technical high school education is vocational training for rapid insertion in the job market. In Brazil, its guiding document is the Ministry of Education's (MEC) National Catalogue of Technical Courses (CNCT), which regulates the supply of 227 technical courses, distributed along 13 technological axes (Brasil, 2017). The pedagogical proposal of technical courses is to develop skills, articulating theory with practice, with a view to professional activities (Brasil, 2017). The curricular planning needs to happen against the background of the professional profile the course intends to prepare, in the context of the occupational structure in the professional area(s), resulting in a specific plan for each of the courses (Cordão, 2002).

In Brazil, technical high school courses are offered at public or private schools. Nevertheless, private schools are confronted with a pressing demand for appropriate infrastructure, rooms and laboratories, teachers, and qualified managers to achieve the desired financial and educational results (Guirado, 2017). Due to this competitiveness, teachers can be constantly charged for results, translated into the school climate, which usually burdens them, putting a strain on 
their physical and mental health and possibly affecting their work (Andrade et al., 2018).

The school climate refers to the teachers, students and managers' shared set of perceptions and expectations, deriving from their experiences within the school regarding the psychosocial atmosphere that influences and receives influence from its dynamics. Thus, it interferes with the quality of life and the teaching-learning process (Moro, Vinha, \& Morais, 2019). Some factors are assessed in this context, including norms, objectives, values, human relations, organization, and the institution's physical, pedagogical and administrative structure. Brazilian studies on the school climate as teachers see it indicate different directions and approaches and tend to focus on public elementary and high schools.

In the state of Espírito Santo, a study was aimed at understanding how elementary and high school teachers perceived and evaluated the school climate and whether the quality of this assessment was associated with the students' school performance. The results indicated that a better school climate improves students' performance (Colombo, 2018). In an elementary and high school in the state of Amazonas, the school climate was assessed based on the teachers' perception of indiscipline and violence, aiming to identify how conflicts were mediated and to propose a structured system for conflict solving. The results revealed that insufficient information led to ineffective conflict resolution strategies and acted as the primary cause of the toxic school climate (Guedes, 2017).

In the research by Ribeiro, Ribeiro, and Tunice (2018), the goal was to reflect on the culture of peace in Brazilian public elementary and high schools and its relationship with the school climate. The results indicated that teachers' constant participation in school decision-making processes enhanced their level of satisfaction, motivation, and responsibility, reflecting a positive school climate and reinforcing the intended culture.

In the international context, studies on the school climate based on teachers' perceptions are more frequent. At a public high school in the state of New Jersey, USA, a survey associated the school climate with the principal's behavior, such as showing appreciation, leadership encouragement, encouragement to take risks, and freedom to make decisions in the relationship with teachers. The results indicated that teachers felt respect, appreciation, encouragement, and support from management, reflecting in a positive school climate (Brown, 2018). In another 
context, the relationship between armed violence and the climate at six public elementary and high schools in one of the school districts in Pennsylvania/USA was evaluated, showing a negative association with the awareness campaigns held (Hartz, 2018).

On the European continent, in a Portuguese study involving 234 public high school teachers, the extent to which the school management's support for teachers influenced their mutual collaboration was analyzed, as well as how this affected the school climate. The results indicated that the management's emotional, informational and professional development support served as predictors of teachers' mutual collaboration and of a positive school climate (Amante, Morgado, \& Silva, 2017).

Specifically regarding the association between school climate and stress, anxiety, and depression, Brazilian studies have indicated different approaches. In the state of Paraná, Nielsen, and Piassa (2012) revealed that physical and mental illness among public school teachers was not associated with the work itself, but with a toxic school climate. On the other hand, in a study conducted in a primary school in Campo Grande, Mato Grosso do Sul, aiming to analyze how teachers perceived the role of their school climate in their working conditions and mental health, no changes were found in their levels of stress, anxiety, and depression (Pereira \& Rebolo, 2017). Similarly, in the research by Souza, Souza and Zechi (2017), developed at public and private elementary and secondary schools in Paranaíba, the objective was to examine the teachers' perception about rules, sanctions and safety in school and the extent to which they were reflected in the school climate, working conditions and in the teachers' mental health. No changes were found in the teachers' stress, anxiety, and depression levels either.

In the international context, a study in central Norway involved 546 municipal secondary school teachers and revealed mental symptoms in more than $50 \%$ of them. This was due to a negative school climate, deriving from pressure for positive results and dissatisfaction with work due to students' discouragement (Skaalvik \& Skaalvik, 2017). On the other hand, in Portugal, a study involving public school teachers from Group D. Pedro I revealed few signs of changes in the teachers' mental health, credited to the fact that $85.7 \%$ of the teachers perceived a positive school climate (Bastos, Lobo, \& Pereira, 2018).

Although stress, anxiety, and depression are frequently associated with the teaching profession in Brazilian (Albuquerque, Petterle, Tostes, \& Silva, 2018) and 
international studies (Narvaéz \& Orosco, 2017), few are focused on technical education. Only a review about two private technical schools in Dourados, State of Mato Grosso do Sul, indicated anxiety and stress levels in all teachers assessed. The causes were linked to difficulties due to the lack of pedagogical training at this level (Hortelan, Missio, Renovato, \& Sgarbi, 2018).

In this sense and considering that competitiveness among private technical schools can affect the school climate and entail risks for the teachers' mental health, a study in this context is relevant and justified. Therefore, in this study, the objective was to evaluate the school climate and indicators of stress, anxiety, and depression in private secondary technical education teachers, particularly focusing on the role and extent to which the school climate affects their stress, anxiety and depression indicators.

\section{Method}

\subsection{Design and participants}

This is an analytical observational study with a cross-sectional and quantitative design. A non-probabilistic convenience sample was selected among technical high-school teachers, affiliated with eight of the 171 private schools in the metropolitan region of Porto Alegre, state of Rio Grande do Sul. More than 120 teachers were invited, 62 of whom agreed to participate. Their mean age was 41.74 years $(S D=12.3)$ and men were predominant $(61.3 \%)$. Most were married (58.1\%), with a mode of one child. The predominant education level was lato sensu graduate education (56.5\%), mean length of teaching experience was 10.32 years $(S D=8.5)$ and mean length of teaching experience in technical education 6.97 years $(S D=5.5)$.

\subsection{Instruments}

- Sociodemographic and Labor Data Questionnaire: self-applied questionnaire, elaborated to collect sample characteristics, containing information about age, sex, marital status, education, function, shift and experience, courses and subjects taught, work regimen, presence of physical or mental illnesses, frequency of medical certificates and requests for leaves of absence from work. 
- The Delaware School Climate Survey - Teacher/Staff - DSCS-T/S [Bear, Gaskins, Pell, \& Yang (2014), being validated in Brazil by Daniele Lindern \& Carolina Saraiva de Macedo Lisboa]: self-applied instrument consisting of two parts. In this study, only the first part was used, which assesses the school climate, based on 39 items in nine factors: 1. teacher-student relationship (attention of the teachers to the students' problems [ $\alpha=0.80]$ ); 2 . student-student relationship (quality of interactions between the students $[\alpha=0.81]$ ); 3 . clarity of expectations (expectations and behavioral rules clear to the students $[\alpha=0.86]$ ); 4 . fairness of rules (fair school rules and consequences [ $\alpha=0.87]$ ); 5 . safety (safety level perceived by the teachers $[\alpha=0.71]$ ); 6 . bullying (level of violence among students $[\alpha=0,73]$ ); 7. student commitment (task completion, respect for rules, and school performance [a = 0.83]); 8. teacher-home communication (quality of communication from teachers to students' parents or guardians [ $\alpha=0.81]$ ); and 9. relationships among employees (level of communication and teamwork among teachers and other school staff [ $\alpha=0.91])$. The questions are answered on a fourpoint Likert scale ( $1=$ "I strongly disagree" to 4 = "I strongly agree"), with interpretation based on the average, so that higher averages represent a higher degree of agreement with the factor.

- Depression, Anxiety and Stress Scale - DASS 21 [Lovibond \& Lovibond (2004), adapted and validated for Brazil by Tucci \& Vignola (2013)]: set of three self-report scales, to be answered on a four-point Likert scale ( 0 = "Does not apply at all" to $3=$ "Applies to me very much or most of the time"). Each scale consists of seven items that measure the emotional states of depression, anxiety and stress. The points on each scale are added up to reveal severity levels: normal, mild, moderate, severe and extremely severe. Good internal consistency measures were found in the validation study (depression: $\alpha=0.92$; anxiety: $\alpha=0.86$; stress: $\alpha=0.90$ ), similar to the current study (depression: $\alpha=0.88$; anxiety: $\alpha=0.84$; stress: $\alpha=0.93$ ).

\subsection{Procedures}

Approval from the Research Ethics Committee of the University of Vale do Rio dos Sinos (Unisinos) was received before the start of the data collection Presentation Certificate of Ethical Appreciation (Certificado de Apresentação de 
Apreciação Ética [CAAE]) No. 84053318.7.0000.5344. Therefore, the boards of the private secondary technical schools were contacted to present the study proposal and obtain authorization for its development. Eight schools gave their consent, being seven located in Porto Alegre and one in Gravataí, in common agreement with the pedagogical sectors, between June and December 2018. The responsible for the pedagogical sector received a link to the online questionnaires by e-mail and forwarded it to the teachers' e-mail addresses.

\subsection{Data analysis}

Descriptive analysis was applied to the data, using frequency distribution, central trend measures (means), and variability measures (standard deviation) to outline the profile of the sample, the school climate and the stress, anxiety and depression indicators. The normality of the data distribution was also studied, using the Kolmogorov-Smirnov test (Lilliefors correction). Furthermore, inferential analyses were applied to the DASS 21 and DSCS-T/C data, aiming to estimate parameters through Spearman's correlation coefficient. Subsequently, multiple regression analysis (stepwise method) was used to determine the predictors of the school climate for stress, anxiety and depression. Therefore, three models were evaluated, one for each indicator. To determine the variables of the school climate used in each initial model, the results of the correlation analysis technique were considered, with significance being set at $20 \%$ or less (Hair, Black, Babin, Anderson, $\&$ Tatham, 2009). All models were defined in one stage. The percentage of variance explained by the model was estimated using the adjusted determination coefficient (adjusted $\mathrm{R}^{2}$ ). SPSS 22.0 (Statistical Package for Social Science) was used for all analyses, considering a significance level of $p \leq 0.05$.

\section{Results}

Regarding the perception of the school climate factors, according to the Delaware School Surveys Interpretation Worksheet - STAFF Version (Bear, Blank, Chen, \& Gaskins, 2018), mean scores superior to three indicate a more favorable climate. Most teachers reported the teacher-student relationship, safety, clarity of expectations and student-student relationship as positive. On the other hand, they indicated more negative perceptions of the fairness of rules and relationships among staff members, study engagement and teacher-home communication. 
Finally, considering that mean scores lower than three are better for bullying, according to the authors, this factor was perceived as positive, that is, the teachers hardly observed bullying in school.

When considering the teachers' responses about the presence of stress, anxiety and depression, the depression factor $(M=4.74, S D=5.39)$ stands out with a higher average score, followed by stress $(M=2.65, S D=4.15)$ and anxiety $(M=$ $2.21, \mathrm{SD}=3.37)$. Regarding the frequency, $80.6 \%$ of teachers were classified as having normal to mild indicators of depression, $6.5 \%$ moderate, and $12.9 \%$ severe to extremely severe. For stress, $83.9 \%$ of the teachers showed normal to mild indicators, $9.7 \%$ moderate, and $6.5 \%$ severe to extremely severe. For anxiety, $85.5 \%$ revealed normal to mild indicators, $4.8 \%$ moderate and $9.7 \%$ severe to extremely severe. The data on the school climate and indicators of stress, anxiety and depression are shown in Table 3.1.

Table 3.1. Factors related to school climate and indicators of stress, anxiety and depression.

\begin{tabular}{llc}
\hline School climate & Mean & $\begin{array}{c}\text { Standard } \\
\text { deviation }\end{array}$ \\
\hline Teacher-student relationship & 3.16 & 0.48 \\
\hline Student-student relationship & 3.01 & 0.48 \\
\hline Clarity of expectations & 3.05 & 0.66 \\
\hline Fairness of rules & 2.93 & 0.76 \\
\hline Safety & 3.10 & 0.62 \\
\hline Bullying & 1.94 & 0.65 \\
\hline Teacher-home communication & 2.61 & 0.71 \\
\hline Relationship between employees & 2.93 & 0.75 \\
\hline Student engagement & 2.66 & 0.49 \\
\hline Emotional conditions & & \\
\hline Stress & 2.65 & 4.15 \\
\hline Anxiety & 2.21 & 3.37 \\
\hline Depression & 4.74 & 5.39 \\
\hline
\end{tabular}


In the relationships between the school climate as perceived by teachers and levels of stress, anxiety and depression, Spearman's correlation analysis showed weak and negative associations. The data are displayed in Table 3.2.

Table 3.2. Correlation between factors related to perceived school climate and indicators of stress, anxiety and depression.

\begin{tabular}{llll}
\hline Factors & Stress & Anxiety & Depression \\
\hline Teacher-student relationship & -0.18 & -0.16 & -0.18 \\
\hline Student-student relationship & $-0.32^{*}$ & $-0.30^{*}$ & $-0.26^{*}$ \\
\hline Clarity of expectations & $-0.29^{*}$ & $-0.28^{*}$ & -0.22 \\
\hline Fairness of rules & $-0.36^{* *}$ & -0.24 & $-0.28^{*}$ \\
\hline Safety & $-0.29^{*}$ & $-0,27^{*}$ & $-0.26^{*}$ \\
\hline Bullying & -0.05 & -0.07 & -0.01 \\
\hline Student engagement & $-0.28^{*}$ & -0.19 & $-0.29^{*}$ \\
\hline
\end{tabular}

Note: $* \mathrm{p}<0.05$ and $* * \mathrm{p}<0.01$

To examine the role of the school climate in the teachers' indicators of stress, anxiety and depression, multiple regression analysis (stepwise model) was applied. According to the results presented in Table 3.3, the lesser degree of agreement on the fairness of the rules explained $16 \%$ of the variance in depression and $15 \%$ of the variance in stress, while the lesser degree of agreement on safety explained $14 \%$ of the variance in anxiety.

Table 3.3. Multiple regression between factors related to perceived school climate and indicators of stress, anxiety and depression

\begin{tabular}{llccccc}
\hline $\begin{array}{l}\text { Variables }- \\
\text { dependent }\end{array}$ & $\begin{array}{l}\text { Variables }- \\
\text { independent }\end{array}$ & $\mathbf{R}$ & $\mathbf{R}^{2}$ & Beta & $\boldsymbol{t}$ & $\boldsymbol{p}$ \\
\hline Stress & Fairness of rules & 0.38 & 0.15 & -0.38 & -3.21 & 0.00 \\
\hline Anxiety & Safety & 0.37 & 0.14 & -0.37 & -3.10 & 0.00 \\
\hline Depression & Fairness of rules & 0.39 & 0.16 & -0.39 & -3.32 & 0.00 \\
\hline
\end{tabular}




\section{Discussion}

Teachers are considered one of the main responsibles in technical education to prepare professionals for the job market (Deitos, Lara, \& Zanardini, 2015). Due to this responsibility, they may suffer charges, threats, and pressure for results, what can affect their mental health, leading to different symptoms and disorders (Cordão, 2002).

In this scenario, the absence of any action relevant to the care for teachers' mental health can generate different school problems, including lack of staff due to sick leave. Nevertheless, at possible risks of dismissal, some teachers fear to be absent, what may affect the level of quality of their praxis affected, thus, impairing the students' learning and the quality of the course (Amorim et al., 2018). More harmful cases are not rare, such as errors in practical activities in situations that entail a risk of death, such as nursing and radiology courses. With the purpose of clarifying the state of teachers' mental health in private technical education courses, in this study, the aim was to assess the relationships between the school climate and indicators of stress, anxiety and depression, as well as the extent to which this climate contributes to those indicators.

Among the participating teachers, we mainly observed normal to mild levels of stress, anxiety and depression. As most teachers had, on average, seven years of teaching experience in technical education and held a graduate degree, they were in better conditions to cope with any difficulties, pressures, and charges they were confronted with at the schools (Cordão, 2002; Custódio \& Nunes, 2019). On the other hand, a smaller part of the sample reported severe to extremely severe suffering. One possible explanation for this was lesser teaching experience in technical education in combination with the lack of a specialization degree in the area (Albuquerque et al., 2018; Hortelan et al., 2018).

In addition, the higher the perceived quality of the student-student relationship and the perceived safety in school, the lower the teachers' indicators of stress, anxiety and depression. It is known that quality interactions between students facilitate the teaching-learning process and the development of interpersonal skills (Cardoso, 2018). Another relevant aspect was the association between the fairness of rules and student engagement on the one hand and lower indicators of stress and depression on the other. School environments with clear and fair rules increase students' perceived equality, respect and belonging. This can enhance teaching work 
through greater participation in the proposed pedagogical activities (Moreno, Pacheco, \& Pacheco, 2018). Furthermore, the data indicated that the clearer the expectations, the lower the indicators of stress and anxiety. Schools with defined rules often further the students' organization, because they are aware of what is expected of their behavior. This creates an orderly environment that facilitates the teaching and entails higher levels of student satisfaction (Coelho \& Dell'Aglio, 2019).

On the other hand, no correlations were observed between stress, anxiety and depression factors with the teacher-student relationship or bullying. This suggests that, among the teachers, the perception of the teacher-student relationship is appropriate, which demonstrates appreciation, respect for differences and attention to difficulties (Machado \& Piton, 2019). Finally, considering that technical courses, in general, have young adult students, mostly working in search for a better qualification, friendships prevail, with few manifestations of violence among students.

Among the influences of the school climate on the teachers' stress, anxiety and depression, it was evidenced that the lesser perception of fairness of the rules contributed to the manifestation of indicators of stress and depression. This result suggests that the teachers perceive that their students did not evaluate the rules in school and the classroom as having equal consequences for all who do not comply, what can lead to relationships marked by disrespect, disinterest, low yield and dropout (Arthur \& Pinto, 2017). Certain rules may not be fulfilling the function of guiding students regarding the expected behavior during the course, and this possible neglect of schools, in the sense that their rules are not fair, is influencing the teachers' emotional state.

Similarly, the lesser perception of safety in school contributed to the development of anxiety indicators among the teachers. Considering that safety refers to the physical well-being of teachers and students when in the school facilities, this result indicates that the space is vulnerable to possible situations of violence and may generate in the teacher a sense of fear and other typical manifestations of an anxious situation. Therefore, on the one hand, safety is considered essential for good relationships between students and their respective commitment (Colombo, 2018), but, on the other, when the safety is not perceived, it seems to clutter the teaching work (Custódio \& Nunes, 2019).

As the literature indicates possible influences of school climate on stress, anxiety, and depression (Pereira \& Rebolo, 2017; Souza et al., 2017; Hortelan 
et al., 2018), the teachers' positive perception of the school climate may explain the fact that the findings showed no expressive influence of these indicators on the teachers' mental health. The data indicated that the teachers valued good coexistence, proper behavior, respect for the rules, student dedication, and school safety. When perceived in a more positive way, these are associated with lower levels of stress, anxiety and depression among teachers, in line with other studies in the area (Amante et al., 2017; Araya et al., 2016; Ribeiro et al., 2018).

Even though private institutions have resisted serving as research fields, for unknown reasons, which limited the access to a larger number of participants, this study partially revealed the environment in which the teachers and students live together. The teachers valued good relationships, mutual respect, clear rules and student dedication, indicating a positive school climate (Aldridge \& Fraser, 2016), without anything causing a greater impact on teachers' mental health. Although the associations are weak, they were present. In view of technical courses' nontransferable mission to prepare skilled workforce for insertion in the labor market, pursuing research on the subject is fundamental, because, if teachers fall ill, it will be hard for them to face that challenge (Coelho \& Dell'Aglio, 2019). Therefore, future research should expand the evaluation of the relationship between variables, such as routine and workload, remuneration, pedagogical training, and how these can affect the mental health of teachers.

\section{References}

Albuquerque, G. S. C., Petterle, R. R., Tostes, M. V., \& Silva, M. J. (2018). Sofrimento mental de professores do ensino público. Saúde em Debate, 42(116), 87-99.

Aldridge, J. M., \& Fraser, B. J. (2016). Teacher's views of their school climate and its relationship with teacher self-efficacy and job satisfaction. Learning Environments Research Journal, 19(2), 291-307.

Amante, L., Morgado, J., \& Silva, J. C. (2017). School climate, principal support and collaboration among Portuguese teachers. European Journal of Teacher Education, $40,505-550$.

Amorim, C. R., Rocha, S. V., Santos, C. A., Santos, L. B., Silva, P. A. S., \& Vilela, A. B. A. (2018). Prevalência de transtornos mentais comuns e fatores associados entre idosos de um município do Brasil. Ciência \& Saúde Coletiva, 23(2), 639-646. 
Andrade, S. M., González, A. D., Mesas, A. E., Salvagione, D. A. J., Santos, H. G., \& Melanda, F. N. (2018). Violência física contra professores no espaço escolar: Análise por modelos de equações estruturais. Cadernos de Saúde Pública, 34(5), 1-12.

Araya, R., Brockman, R., Campbell, R., Ford, T., Gunnell, D., Kidger, J., King, M., \& Tilling, K. (2016). Teachers' wellbeing and depressive symptoms, and associated risk factors: A large cross sectional study in English secondary schools. Journal of Affective Disorders, 192, 76-82.

Arthur, D. C. S., \& Pinto, L. A. (2017). Estudo da prática da docência no ensino técnico: Aplicação e análise sobre um aspecto dos desafios encontrados no setor. Revista InterAtividade, 5(1), 147-154.

Bastos, F., Lobo, C. C., \& Pereira, C. S. (2018). Práticas pedagógicas num território educativo de intervenção prioritária. Revista Educação e Pesquisa, 44, 1-22.

Bear, G., Blank, J. C., Chen, F. F., \& Gaskin, C. (2018). Delaware School Surveys Interpretation Worksheet - Staff Version. Retrieved from http://wh1.oet.udel.edu/pbs/wp-content/ uploads/2019/05/SCS-Interpret-Worksheet-2018-19-STAFF.docx

Bear, G. G., Gaskins, C., Pell, M., \& Yang, C. (2014). Validation of a brief of teachers' perceptions of school climate: Relations to student achievement and suspensions. Learning Environments Research, 17, 339-354.

Brasil (2017). Catálogo Nacional de Cursos Técnicos. Retrieved from http://portal.mec.gov. br/auditorias/3000o-uncategorised/52031-catalogo-nacional-de-cursos-tecnicos

Brown, C. (2018). Teacher and principal perceptions of deliberate principal behaviors related to school climate. Doctoral Dissertation, Columbus State University, Columbus, Georgia, USA.

Cardoso, A. C. S. 2018. O feedback aluno-aluno em um ambiente virtual de aprendizagem. Trabalhos em Linguística Aplicada, 51(1), 383-409.

Coelho, C. de A., \& Dell'Aglio, D. D. (2019). Clima escolar e satisfação com a escola entre adolescentes de ensino médio. Psicologia: Teoria e Prática, 21(1), 248-264.

Colombo, T. F. S. (2018). A convivência na escola a partir da perspectiva de alunos e professores: Investigando o clima e sua relação com o desempenho escolar em uma instituição de ensino fundamental Il e médio. Tese de doutorado, Universidade Estadual Paulista, Marília, SP, Brasil.

Cordão, F. A. (2002). A LDB e a nova educação profissional. Boletim Técnico Do Senac, $28(1), 10-23$. 
Custódio, G. C. C., \& Nunes, C. M. F. (2019). A docência em "celas de aula": Desafios dos professores de educação física em escolas prisionais. Reflexão e Ação, 27(2), 130-147.

Deitos, R. A., Lara, A. M. B., \& Zanardini, I. M. S. (2015). Política de educação profissional no Brasil: Aspectos socioeconômicos e ideológicos para a implantação do Pronatec. Educação \& Sociedade, 36(133), 985-1001.

Guedes, F. C. (2017). Gestão do conflito e clima escolar: um estudo de caso em uma escola estadual do Amazonas. Dissertação de mestrado, Universidade Federal de Juiz de Fora, Juiz de Fora, MG, Brasil.

Guirado, G. M. P. (2017). Transtornos mentais comuns e suas peculiaridades com o trabalho. Saúde em Foco, 9, 162-170.

Hair, J. F., Black, W. C., Babin, B. J., Anderson, R. E., \& Tatham, R. L. (2009). Análise multivariada de dados. Porto Alegre: Bookman.

Hartz, A. M. (2018). Teacher perceptions of school gun violence. Doctoral Dissertation, Temple University, Philadelphia, Pennsylvania, USA.

Hortelan, M. P. S. M., Missio, L., Renovato, R. D., \& Sgarbi, A. K. G. (2018). Enfermeiro docente no ensino técnico em enfermagem. Laplage em Revista, 4(1), 254-273.

Lovibond, S. H., \& Lovibond, P. F. (2004). Manual for the Depression Anxiety Stress Scales (4th ed.). Sydney: Psychology Foundation.

Machado, C., \& Piton, N. N. (2019). Clima escolar: Mapeamento e análise de artigos científicos constantes no portal de periódico Capes. Revista @mbienteeducação, 12(1), 50-67.

Moreno, T. M., Pacheco, M. da S., \& Pacheco, P. M. (2018). O quê e a quem se quer ensinar: análise das propostas pedagógicas, missões e valores das escolas com os melhores resultados no Enem. Interfaces da Educação, 9(25), 270-290.

Moro, A., Vinha, T. P., \& Morais, A. de (2019). Avaliação do clima escolar: Construção e validação de instrumentos de medida. Cadernos de Pesquisa, 49(172), 312-334.

Narvaéz, F. S., \& Orosco, J. J. V. (2017). Comorbilidad entre síndrome de burnout, depresión y ansiedad en una muestra de profesores de educación básica del Estado de México. Revista Papeles de Población, 23(94), 261-286.

Nielsen, M., \& Piassa, Z. A. C. (2012). O "trabalho" e sua relação com o adoecimento físico/mental do professor readaptado na escola pública do estado do Paraná. In Secretaria da Educação do Estado do Paraná, o professor PDE e os desafios da escola pública paranaense: Produção didático-pedagógica (vol. II). Retrieved from http:// 
www.diaadiaeducacao.pr.gov.br/portals/cadernospde/pdebusca/producoes_ pde/2012/2012_uel_ped_pdp_maurenia_nielsen.pdf

Pereira, P. P., \& Rebolo, F. (2017). Clima escolar e suas implicações para o trabalho docente. Série-Estudos, 22(46), 93-112.

Ribeiro, M. T. M., Ribeiro, S. L. S., \& Tunice, L. M. C. (2018). A influência da cultura e do clima escolar na construção e fortalecimento da cultura de paz. Revista Educação, Cultura e Comunicação, 9(17), 309-320.

Skaalvik, E. M., \& Skaalvik, S. (2017). Still motivated to teach? A study of school context variables, stress and job satisfaction among teachers in senior high school. Journal of Social Psychology of Education, 20, 15-37.

Souza, A. E. M. T., Souza, M. L. de, \& Zechi, J. A. M. (2017). Avaliando o clima escolar em escolas de Paranaíba-MS: Uma análise das regras, das sanções e da segurança nas escolas. Anais do Seminário de Educação e Colóquio de Pesquisa, Paranaíba, MS, Brasil.

Tucci, A. M., \& Vignola, R. C. B. (2013). Adaptation and validation of the Depression, Anxiety and Stress Scale (DASS) to Brazilian Portuguese. Journal of Affective Disorders, 155, 104-109.

\section{Authors notes}

Osvaldo André Filippsen, Administration Department (AD), Porto Alegre Technical Institute of Education (Fatepa); Angela Helena Marin, Department of Developmental and Personality Psychology (DPDP), Federal University of Rio Grande do Sul (UFRGS).

Article derived from the dissertation of Osvaldo André Filippsen, carried out under the supervision of Angela Helena Marin, presented in the Graduate Program in Psychology at the University of Vale do Rio dos Sinos.

Correspondence concerning this article should be addressed to Osvaldo André Filippsen, Rua General Vitorino, 229, Centro Histórico, Porto Alegre, RS, Brazil. CEP 90020-121.

E-mail: educador.osvaldo@gmail.com 